\title{
RUSSIANS ABROAD
}

Literary and Cultural Politics of Diaspora (1919-1939) 


\section{The Real Twentieth Century}

Series Editor - Thomas Seifrid (University of Southern California) 


\section{RUSSIANS ABROAD}

Literary and Cultural Politics of Diaspora (1919-1939)

GRETA N. SLOBIN

Edited by Katerina Clark, Nancy Condee, Dan Slobin, and Mark Slobin 
Library of Congress Cataloging-in-Publication Data:

The bibliographic data for this title is available from the Library of Congress.

Copyright () 2013 Academic Studies Press

All rights reserved

ISBN 978-1-61811-214-9 (cloth)

ISBN 978-1-61811-215-6 (electronic)

Cover illustration by A. Remizov from "Teatr," Center for Russian Culture, Amherst College.

Cover design by Ivan Grave.

Published by Academic Studies Press in 2013.

28 Montfern Avenue

Brighton, MA 02135, USA

press@academicstudiespress.com

www.academicstudiespress.com 


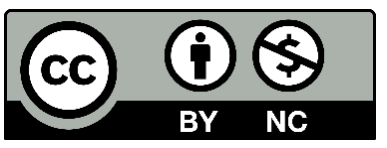

Effective December 12th, 2017, this book will be subject to a CC-BY-NC license. To view a copy of this license, visit https://creativecommons.org/licenses/by-nc/4.0/. Other than as provided by these licenses, no part of this book may be reproduced, transmitted, or displayed by any electronic or mechanical means without permission from the publisher or as permitted by law.

The open access publication of this volume is made possible by:

THE

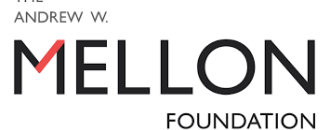

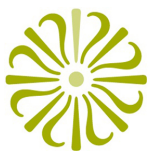

NATIONAL ENDOWMENT FOR THE HUMANITIES

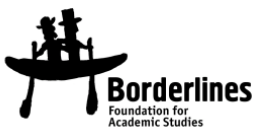

This open access publication is part of a project supported by the National Endowment for the Humanities and The Andrew W. Mellon Foundation Humanities Open Book initiative, which includes the open access release of several Academic Studies Press volumes. To view more titles available as free ebooks and to learn more about this project, please visit borderlinesfoundation.org/open.

Published by Academic Studies Press

28 Montfern Avenue

Brighton, MA 02135, USA

press@academicstudiespress.com

www.academicstudiespress.com 


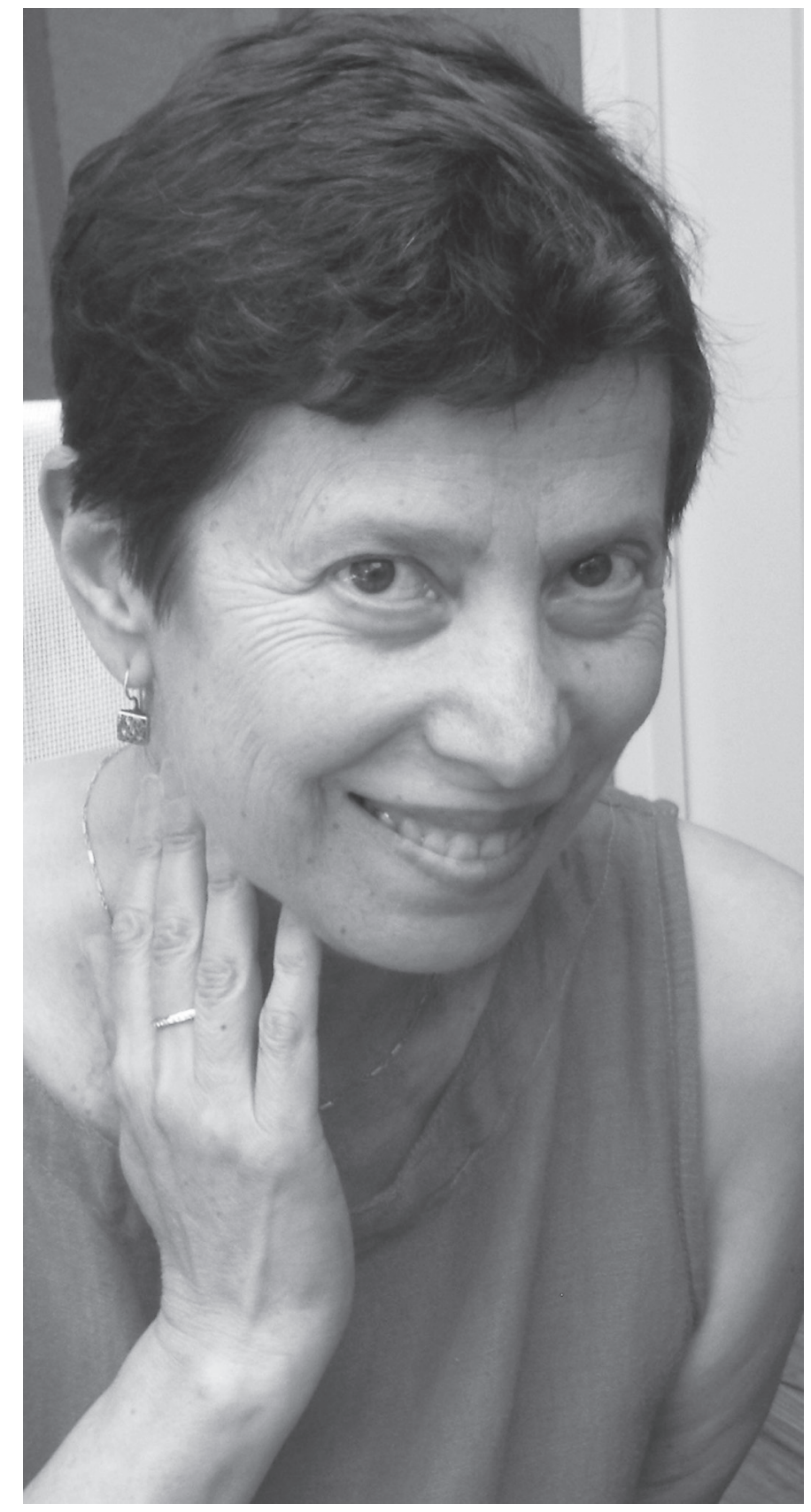

